Postgraduate Bosowa University Publishing (PBUP)
Indonesian Journal of Business and Management
e-ISSN: $2460-3767 \quad p$-ISSN: $2656-6885$
Inttps://postgraduate.universitasbosowan
JOURAL

\title{
ANALISIS EFEKTIVITAS PROGRAM PENYELENGGARAAN DIKLAT KANTOR PPSDM KEMENDAGRI REGIONAL MAKASSAR TERHADAP KINERJA ASN
}

\section{The Analysis of Training Program Effectivity by PPSDM Ministry of Home Affairs in Makassar towards Civil Cervants Performance}

\author{
Fifi Asfiah ${ }^{1}$, Muhlis Ruslan ${ }^{2}$ dan Chahyono ${ }^{3}$ \\ ${ }^{1}$ Mahasiswa Magister Manajemen Universitas Universitas Bosowa \\ ${ }^{2}$ Program Studi Manajemen Program Pascasarjana Universitas Bosowa \\ Email: fifiasfiah18@gmail.com
}

Diterima: 22 Januari 2021/Disetujui: 02 Juni 2021

\begin{abstract}
ABSTRAK
Tujuan penelitian ini untuk mengetahui sejauh mana pengaruh pendidikan dan pelatihan terhadap kinerja ASN melalui efektifitas program diklat pada Kantor PPSDM Kemendagri Regional Makassar. Jumlah responden sebanyak 222 orang yaitu pegawai dan peserta pelatihan yang dilakukan pada kantor tersebut. Metode analisis yang digunakan adalah regresi berganda melalui pendekatan jalur atau path. Hasil analisis menunjukan bahwa pendidikan dan pelatihan berpengaruh positif dan signifikat terhadap efektivitas program diklat dan kinerja ASN secara langsung, artinya koefisien regresi yang dihasilakan bertanda positif dengan tingkat signifikan yang lebih kecil dari signifikasi standar jika dihubungkan secara langsung atau tanpa dimediasi variable lain. Efektifitas program diklat juga memiliki pengaruh positif dan signifikat terhadap kinerja ASN secara langsung, koefisien regresi yang dihasilakan bertanda positif dengan tingkat signifikan yang lebih kecil dari signifikasi standar jika dihubungkan secara langsung atau tanpa dimediasi variable lain. Untuk mengukur hubungan tidak langsung antara pendidikan dan pelatihan terhadap kinerja ASN melalui efektifitas program diklat hasil yang ditunjukan bahwa pendidikan dan pelatihan memiliki hubungan positif dan signifikan terhadap kinerja ASN melalui efektifitas program diklat. Hubungan tidak langsung memiliki koefisien regresi yang lebih besar dari hubungan langsung yang terjadi. Hal ini diperoleh dari nilai koefisien total yang lebih besar.
\end{abstract}

Kata Kunci: Pendidikan, Pelatihan, Kinerja, Efektivitas Program Diklat

\begin{abstract}
The purpose of this study was to determine the extent of the influence of education and training on the performance of ASN through the effectiveness of the education and training program at Regional PPSDM Minstry of Home Affairs Makassar. The number of respondents was 222 people consisting of employees and trainees, conducted at the office. The data was analysed using multiple regression analysis through the path approach. The results show that education and training have a positive and significant effect on the effectiveness of the training program and ASN performance directly. The effectiveness of the training program also has a positive and significant influence on ASN performance directly. To measure the indirect relationship between education and training on ASN performance through the effectiveness of the education and training program, a second regression was conducted. The results show that education and training have a positive and significant relationship to ASN performance through the effectiveness of the education and training program. Indirect relationship has a regression coefficient that is greater than the direct relationship that occurs. This is obtained from the larger total coefficient.
\end{abstract}

Keywords: Education, Training, Performance, Training Program Effectivity 


\section{PENDAHULUAN}

Ketahanan organisasi didukung oleh sumber daya manusia yang memiliki kompetensi. Setiap sumber daya manusia yang berkompeten tentunya dibekali oleh kemampuan yang sangat dibutuhkan organisasi dalam pencapaian tujuannya. Sehingga tentunya organisasi menuntut sumber daya manusianya memiliki daya kompetensi yang berdaya saing. Kompetensi pada sumber daya manusia tentunta dapat meningkat dengan berbagai cara. Salah satunya adalah dengan memberikan pendidikan serta pelatihan. Pendidikan dan pelatihan yang diberikan organisasi sebagai konsep pengembangan sumber daya manusia berbasis kompetensi. Hal ini merupakan salah satu langkah yang dilakukan agar dapat memberikan hasil yang sesuai dengan tujuan dan sasaran organisasi. Metode pelatihan (training) merupakan salah satu metode yang paling banyak ditempuh. Alasannya, metode pelatihan dapat meningkatkan nilai tambah karyawan (employee value).

UU ASN (UU Nomor 5 Tahun 2014) adalah berkaitan dengan Manajemen ASN diselenggarakan berdasarkan Sistem Merit, yang berdasarkan pada kualifkasi, kompetensi, dan kinerja secara adil dan wajar dengan tanpa membedakan latar belakang poltik, ras, warna kulit, agama, asal-usul, jenis kelamin, status pernikahan, umum, atau kondisi kecacatan. Manajemen ASN ini meliputi Manajemen Pegawai Negeri Sipil (PNS) dan Manajemen Pegawai Pemerintah dengan Perjanjian Kerja (PPPK). Disebutkan dalam Undang-Undang Nomor 5 Tahun 2014 itu, Presiden dapat mendelegasikan kewenangan pembinaan Manajemen ASN kepada Pejabat yang Berwenang di kementerian, sekretariat jendral/sekretariat lembaga negara, sekretariat lembaga nonstruktural, sekretaris daerah/provinsi dan kabupaten/kota.

Pasal 56 UU ini menegaskan, setiap Instansi Pemerintah wajib menyusun kebutuhan jumlah dan jenis jabatan PNS berdasarkan analisis jabatan dan analisis beban kerja. Penyusunan kebutuhan sebagaimana dimaksud dilakukan untuk jangka waktu 5 (lima) tahun yang diperinci per 1 (satu) tahun berdasarkan prioritas kebutuhan. Berdasarkan penyusunan kebutuhan ini, Menteri Pendayagunaan Aparatur Negara dan Reformasi Birokrasi (PAN-RB) menetapkan kebutuhan jumlah dan jenis jabatan PNS secara nasional. Adapun dalam hal pengadaan, ditegaskan Pasal 58 UU No.5/2014 ini, bahwa pengadaan PNS merupakan kegiatan untuk mengisi kebutuhan Jabatan Administrasi dan/atau Jabatan Fungsional dalam suatu Instansi Pemeirntah, yang dilakukan berdasarkan penetapan kebutuhan yang ditetapkan oleh Menteri PAN-RB. "Pengadaan PNS sebagaimana dimaksud dilakukan melalui tahapan perencanaan, pengumuman lowongan, pelamaran, seleksi, pengumuman hasil seleksi, masa percobaan, dan pengangkatan menjadi PNS," bunyi Pasal 58 Ayat (4) UU No. 5/2014 ini.

\section{METODE}

Dalam menganalisi data dalam penelitian ini, adalah dengan menggunakan nilai-nilai dari koesioner yang telah dibagikan kepada responden kemudian mengolah dengan menggunakan SPSS. Analisis data yang digunakan dalam penelitian ini meliputi:

1) Analisis Jalur

Analisis jalur sendiri tidak menentukan hubungan sebab-akibat dan juga tidak dapat digunakan sebagai subtitusi bagi peneliti untuk melihat hubungan kausalitas antar variabel. Hubungan kausalitas antar variabel telah dibentuk dengan model berdasarkan landasan teoritis. Apa yang dilakukan oleh analisis jalur adalah menentukan pola hubungan antara tiga atau lebih variabel dan tidak dapat digunakan untuk mengkonfirmasi atau menolak hipotesis kausalitas imajiner. Dalam analisis jalur, digunakan adalah:

a. Diagram Jalur dan Persamaan Struktural

Dalam analisis jalur sebelum peneliti melakukan analisis suatu penelitian, terlebih dahulu peneliti membuat diagram jalur yang digunakan untuk mempresentasikan permasalahan dalam bentuk gambar dan menentukan persamaan struktural yang menyatakan hubungan antar variabel pada diagram jalur tersebut. Diagram jalur dapat digunakan untuk menghitung pengaruh langsung dan tidak langsung dari variabel Independen terhadap suatu variabel dependen. Pengaruh-pengaruh itu tercermin dalam apa yang disebut dengan koefisien jalur, dimana secara matematik analisis jalur mengikuti model structural. Berikut di uraikan model persamaan structural analisis jalur.

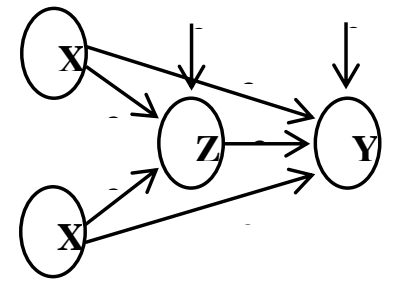

Gambar 1. Diagram Jalur

$$
\begin{gathered}
Z=Z_{1}+\rho Z X_{2}+e_{1} \text { Substruktural } 1 \\
Y=\rho X_{1}+\rho Y_{2}+\rho Y Z+e_{2} \text { Substruktural } 2
\end{gathered}
$$

Dimana:

$X 1=$ Pendidikan

$\mathrm{X} 2=$ Pelatihan

$\mathrm{Y} \quad=$ Kinerja ASN

$\mathrm{Z} \quad=$ Efektivitas program DIKLAT

$\rho \quad=$ Koefisien Jalur

$\mathrm{e}_{1} \mathrm{e}_{2} \quad=$ Faktor lain yang mempengaruhi 
Untuk memperoleh nilai koefisien jalur dari masingmasing variabel Independen, terlebih dahulu dihitung korelasi antar variabel menggunakan rumus korelasi Pearson Product Moment sebagai berikut:

$$
r_{X Y}=\frac{N \sum X Y-\left(\sum X\right)(\Sigma Y)}{\sqrt{\left\{N \sum X^{2}-\left(\sum X^{2}\right)\right\}\left\{N \sum Y^{2}-\left(Y^{2}\right)\right\}}}
$$

Nilai Korelasi yang diperoleh dapat diinterpertasikan dengan berpedoman pada Tabel Berikut

Tabel 1. Interpertasi Nilai Kofesien Korelasi

\begin{tabular}{ll}
\hline \multicolumn{1}{c}{ Interval Kofesien } & \multicolumn{1}{c}{ Tingkat hubungan } \\
\hline $0,00-0,199$ & Sangat Rendah \\
$0,20-0,399$ & Rendah \\
$0,40-0,599$ & Sedang \\
$0,60-0,799$ & Kuat \\
$0,80-1,000$ & Sangat kuat \\
\hline Sur $:$ Sugio
\end{tabular}

Sumber : Sugiono (2014)

2) Uji Hipotesis

Pembuktian hipotesis yang di ajikan dalam penelitian ini dilakukan dengan melakukan pengujian terhadap hipotesis. Pengujian hipotesis dilakukan dengan menggunakan uji parsial (t) dan uji simultan (F) yang diuraikan sebagai berikut:

a) Pengujian parsial (t)

Analisis uji parsial (t) dilakukan untuk membuktikan pengaruh signifikan antara variable independen terhadap variable dependen. Dengan melakukan perbandingan antara nilai $t$ hitung $\left(t_{\text {hitung }}\right)$ dan $t$ tabel $\left(t_{\text {tabel }}\right)$. Penunjukan diterimahnya hipotesis jika $t$ hitung lebih besar dari $t$ table $\left(t_{\text {hitung }}>t_{\text {table }}\right), t$ table $\left(t_{\text {table }}\right)$ diperoleh dari banyaknya observasi dikurang banyaknya variable yang digunakan (n $-\mathrm{k}-1$ ), dimana derajat signifikan yang digunakan adalah lebih kecil $\alpha=0,05$, artinya nilai signifikan harus lebih kecil dari derajat kepercayaan $(\alpha)$ atau probabilita. Diketahui $\mathrm{t}$ tabel adalah $(222-4-1=217)$ dengan signifikan 0.05 sebesar $1.970956(1,971)$

b) Pengujian Simultan (F)

Uji $F$ digunakan untuk mengetahui pengaruh variabel independen secara serentak terhadap variabel dependen. Dalam penelitian ini variabel independen terdiri dari pendidikan $\left(\mathrm{X}_{1}\right)$, dan pelatihan $\left(\mathrm{X}_{2}\right)$. Variabel intervening efektifitas pelatihan (Z). Sedangkan variabel dependen adalah kinerja pegawai (Y). Untuk mengetahui apakah hipotesis diterima atau tidak, maka $\mathrm{F}$ hitung harus lebih besar dari $\mathrm{F}$ tabel $\left(\mathrm{F}_{\text {hitung }}>\mathrm{F}_{\text {tabel }}\right)$ melaui sig, $\alpha=$ 0,05 . Untuk mengetahui apakah hipotesis diterima atau tidak, maka $\mathrm{F}$ hitung harus lebih besar dari $\mathrm{F}$ tabel $\left(\mathrm{F}_{\text {hitung }}\right.$ $\left.>\mathrm{F}_{\text {tabel }}\right)$ melaui sig, $\alpha=0,05$. Untuk mengetahui nilai $\mathrm{F}$ tabel $\left(\mathrm{F}_{\text {tabel }}\right)$ dilakukan dengan melihat tabel titik persentase distribusi $\mathrm{F}$ dengan probabilitas 0,05 dimana $\mathrm{df}_{1}$ adalah $\mathrm{k}-1$ dan $\mathrm{df}_{2}$ adalah $\mathrm{n}-\mathrm{k}$ sehingga diperoleh $\mathrm{F}$ tabel $\left(\mathrm{F}_{\text {tabel }}\right)$. Diketahui $\mathrm{df}_{1}(4-1=3)$ dan $\mathrm{df}_{2}(222-4=$ 218) dengan signifikan 0.05 maka $F$ tabel sebesar $2.646014(2,646)$.

Populasi adalah wilayah generalisasi yang terdiri atas subjek/objek yang mempunyai kualitas dan karakteristik tertentu yang ditetapkan oleh untuk dipelajari dan ditarik kesimpulannya. Populasi sering juga dikatakan seluruh anggota yang tergabung dalam sebuah ikatan dalam sebuah wilayah tertentu. Dalam penelitian ini didapatkan populasi adalah seluruh ASN Pada Kantor PPSDM Kemendagri Regional Makassar yang berjumlah sebanyak 499 orang.

Sampel adalah bagian dari jumlah populasi yang diambil menurut teknik pengambilan sampling. Sampel diambil jika populasi terlalu banyak, sehingga sangat sulit untuk dipelajari. Sampel merupakan perwakilan dari populasi yang dianggap layak mewakili populasi.

Melihat populasi dalam penelitian terlalu banyak, sehingga memberikan kesulitan bagi peneliti dalam menghimpun seluruh populasi, maka digunakan teknik pengambilan sampling cara probality sampling yang merupakan gambaran bahwa semua populasi berkesempatan menjadi sampel. Dalam penarikan dan penentuan sampel, digunakan metode sloving dengan rumus:

$$
\mathrm{n}=\frac{\mathrm{N}}{1+\mathrm{N}(\mathrm{e})^{2}}
$$

Dari rumus sloving tersebut maka diketahui jumlah sampel yang digunakan dalam penelitian ini adalah:

$$
\begin{aligned}
& \mathrm{n}=\frac{449}{1+449(0,05)^{2}} \\
& \mathrm{n}=\frac{449}{1+449(0.0025)} \\
& \mathrm{n}=\frac{449}{1+1,2475} \\
& \mathrm{n}=\frac{449}{2,2475} \\
& \mathrm{n}=222,02 \\
& \mathrm{n}=222 \text { exampler }
\end{aligned}
$$

Sampel yang digunakan adalah 222 orang dengan spesifikasi, seluruh ASN Kantor PPSDM Kemendagri Regional Makassar serta peserta yang telah mengikuti Diklat yang di laksanakan oleh Kantor PPSDM Kemendagri Regional Makassar. Klasifikasi sampel dibagi atas Jenis Kelamin, Golongan, Tingkat Pendidikan, dan Lama Bekerja.

\section{HASIL DAN PEMBAHASAN}

Untuk menganalisis sejauh mana pengaruh pendidikan dan pelatihan terhadap kinerja ASN melalui 
efektivitas program diklat pada PPSDM Kemendagri Regional Makassar, dilakukan dengan menggunakan analisis regresi linear berganda. Analisis berganda dilakukan sebanyak dua kali. Hal ini karena hadirnya variabel penghubung antara variabel independen terhadap dependen atau dengan kata lain mengukur hubungan langsung dan hubungan tidak langsung antara variabel. Analisis dilakukan berdasarkan nilai dari standardized coefficients hasil regresi antara pengaruh pendidikan, pelatihan, dan efektivitas program diklat terhadap kinerja ASN.

Untuk lebih jelas akan disajikan hasil olahan data dengan menggunakan program statistical package for the social sciences (SPSS) dengan dua persamaan, yaitu

a. Persamaan I (Pengaruh pendidikan dan pelatihan terhadap efektivitas program diklat). Hubungan antara pendidikan dan pelatihan terhadap efektivitas program diklat dapat dilihat sebagai berikut:

$$
\mathrm{Z}=-1.521+0.106 \mathrm{x}_{1}+0.152 \mathrm{x}_{2}
$$

1) Konstanta (a) sebesar $-1,521$, artinya jika semua variabel bebas yaitu pendidikan dan pelatihan memiliki nilai 0 , maka efektivitas program diklat (Z) memiliki nilai sebesar -1,521.

2) Koefisien regresi (b1) untuk variabel pendidikan (X1) sebesar 0,106; artinya jika pendidikan mengalami kenaikan sebesar 1 satuan, maka efektivitas program diklat (Z) akan mengalami peningkatan sebesar 0,106 . Koefisien bernilai positif antara pendidikan dan efektivitas program diklat. Dapat dilihat bahwa variable pendidikan berpengaruh positif atau searah terhadap variable efektivitas program diklat. Hal ini berdasarkan jawaban responden mengenai variable pendidikan bahwa hendaknya kurikulum disusun dan diberikan harus sesuai dengan kebutuhan tujuan pendidikan tersebut, yang kebanyakan responden menjawab setuju dengan persentase $42,34 \%$. Untuk pertnyaan selanjutnya kurikulum dalam pendidikan perlu mengikuti perkembangan jaman, sehingga perlu pengembangan kurikulum dari waktu ke waktu, kebanyakan responden menjawab setuju dengan persentase $36.04 \%$. Untuk pertanyaan mengenai keberhasilan suatu pendidikan, di pengaruhi oleh metode yang digunakan tenaga pengajar, kebanyakan responden menjawab setuju dengan persentase $42.79 \%$. Selanjutnya untuk pertanyaan dalam suatu diklat ada beberapa karakteristik dari peserta, sehingga dibuthkan metode pengajaran yang sifatnya fleksibel untuk mempermudah keterterimaan bahan ajar kepada peserta. Kebanyakan responden menjawab setuju dengan persentase $36.49 \%$. Selanjutnya untuk mengukur sejauh mana keterterimaan materi pendidikan, maka perlu dilakukan evaluasi untuk peserta. Kebanyakan responden menjawab setuju dengan persentase $35,59 \%$. Pertanyaan selanjutnya yaitu bentuk evaluasi, harus sesuai dengan maksud dan tujuan pendidikan. Kebanyakan responden menjawab setuju dengan persentase $35,06 \%$.

3) Koefisien regresi (b2) untuk variabel pelatihan (X2) sebesar 0,152 ; artinya jika pelatihan mengalami kenaikan sebesar 1 satuan, maka efektivitaas program diklat (Z) akan naik sebesar 0,152. Koefisien bernilai positif antara pelatihan dan efektivitas program diklat. Dapat dilihat bahwa variable pelatihan memiliki hubungan yang searah terhadap efektivitas diklat, hal ini ditunjukan dengan nilai positif dan derajat signfikan lebih kecil dari nilai standar. Hal ini berarti bahwa variable pelatihan dengan indicator yang di sajikan melalui pertanyaan dengan jawaban responden memiliki pengaruh kuat untuk meningkatkan efektivitas diklat. Pertanyaan pertama yaitu pelatihan yang dilaksakan, harus sesuai dengan kebutuhan instansi dan tujuan dari pelatihan itu. Kebanyakan responden menjawab setuju dengan persentase $40,09 \%$. Untuk pertanyaan selanjutnya, peserta yang di terima harus memenuhi spesifikasi sebagai persyaratan peserta tanpa terkecuali. Kebanyakan responden menjawab setuju dengan persentase $36,49 \%$. Selanjutnya untuk pertanyaan instuktur dalam Diklat perlu memiliki kompetensi yang sesuai dengan materi yang akan di bawakan untuk peserta. Kebanyakan responden menjawab setuju dengan persentase $49,55 \%$. Pertanyaan selanjutnya spesifikasi instruktur dalam Diklat harus di tentukan, untuk menjaga arah dan tujuan kegiatan. Kebanyakan responden menjawab setuju dengan persentase $42,79 \%$. Selanjutnya dalam pelaksanaan Diklat, waktu yang digunakan harus sesuai dengan kebutuhan program Diklat tersebut. Kebanyakan responden menjawab setuju dengan persentase $36,94 \%$. Selanjutnya pertanyaan pengaturan schedule harus diperhatikan, agar dapat terjadi ketepatan waktu pelaksanaan Diklat. Kebanyakan responden menjawab setuju dengan persentase $30,63 \%$.

b. Persamaan II (Pengaruh pendidikan, pelatihan, dan efektivitas program diklat terhadap kinerja ASN)

Hubungan antara pendidikan, pelatihan, dan efektivitas program diklat terhadap kinerja ASN dapat dilihat sebagai berikut:

$\mathrm{Y}=1.438+0.170 \mathrm{x}_{1}+0.159 \mathrm{x}_{2}+0.120 \mathrm{z}$

Dari hasi regresi tersebut, dapat dilihat bahwa:

1) Konstanta (a) sebesar 1,438, artinya jika semua variabel bebas yaitu pendidikan,pelatihan, dan efektivitas program diklat memiliki nilai 0 , maka kinerja ASN (Y) memiliki nilai sebesar 1,438. Hal ini menunjukan bahwa ada variable lain yang dapat mempengaruhi kinerja ASN di luar variable pendidikan, pelatihan, dan efektivitas diklat pada PPSDM Regional Makassar.

2) Koefisien regresi (b1) untuk variabel pendidikan (X1) sebesar 0,170; artinya jika pendidikan mengalami kenaikan sebesar 1 satuan, maka kinerja ASN (Y) akan mengalami peningkatan sebesar 
0,170 . Koefisien bernilai positif antara pendidikan dan kinerja ASN. Hal ini menunjukan bahwa variable pendidikan memiliki hubungan searah dengan kinerja ASN. Indikator yang digunakan untuk mengukur pendidikan yaitu kurikulum disusun dan diberikan harus sesuai dengan kebutuhan tujuan pendidikan tersebut, yang kebanyakan responden menjawab setuju dengan persentase $42,34 \%$. Untuk pertnyaan selanjutnya kurikulum dalam pendidikan perlu mengikuti perkembangan jaman, sehingga perlu pengembangan kurikulum dari waktu ke waktu, kebanyakan responden menjawab setuju dengan persentase $36.04 \%$. Untuk pertanyaan mengenai keberhasilan suatu pendidikan, di pengaruhi oleh metode yang digunakan tenaga pengajar, kebanyakan responden menjawab setuju dengan persentase $42.79 \%$. Selanjutnya untuk pertanyaan dalam suatu diklat ada beberapa karakteristik dari peserta, sehingga dibuthkan metode pengajaran yang sifatnya fleksibel untuk mempermudah keterterimaan bahan ajar kepada peserta. Kebanyakan responden menjawab setuju dengan persentase $36.49 \%$. Selanjutnya untuk mengukur sejauh mana keterterimaan materi pendidikan, maka perlu dilakukan evaluasi untuk peserta. Kebanyakan responden menjawab setuju dengan persentase $35,59 \%$. Pertanyaan selanjutnya yaitu bentuk evaluasi, harus sesuai dengan maksud dan tujuan pendidikan. Kebanyakan responden menjawab setuju dengan persentase $35,06 \%$.

3) Koefisien regresi (b2) untuk variabel pelatihan (X2) sebesar 0,159; artinya jika pelatihan mengalami kenaikan sebesar 1 satuan, kinerja ASN (Y) akan naik sebesar 0,159. Koefisien bernilai positif antara pelatihan dan kinerja ASN. Dapat dilihat bahwa variable pelatihan memiliki hubungan yang searah terhadap kinerja ASN, hal ini ditunjukan dengan nilai positif dan derajat signfikan lebih kecil dari nilai standar. Hal ini berarti bahwa variable pelatihan dengan indicator yang di sajikan melalui pertanyaan dengan jawaban responden memiliki pengaruh kuat untuk meningkatkan efektivitas diklat. Pertanyaan pertama yaitu pelatihan yang dilaksakan, harus sesuai dengan kebutuhan instansi dan tujuan dari pelatihan itu. Kebanyakan responden menjawab setuju dengan persentase $40,09 \%$. Untuk pertanyaan selanjutnya, peserta yang di terima harus memenuhi spesifikasi sebagai persyaratan peserta tanpa terkecuali. Kebanyakan responden menjawab setuju dengan persentase $36,49 \%$. Selanjutnya untuk pertanyaan instuktur dalam Diklat perlu memiliki kompetensi yang sesuai dengan materi yang akan di bawakan untuk peserta. Kebanyakan responden menjawab setuju dengan persentase $49,55 \%$. Pertanyaan selanjutnya spesifikasi instruktur dalam Diklat harus di tentukan, untuk menjaga arah dan tujuan kegiatan. Kebanyakan responden menjawab setuju dengan persentase $42,79 \%$. Selanjutnya dalam pelaksanaan Diklat, waktu yang digunakan harus sesuai dengan kebutuhan program Diklat tersebut. Kebanyakan responden menjawab setuju dengan persentase $36,94 \%$. Selanjutnya pertanyaan pengaturan schedule harus diperhatikan, agar dapat terjadi ketepatan waktu pelaksanaan Diklat. Kebanyakan responden menjawab setuju dengan persentase $30,63 \%$.

4) Koefisien regresi (b3) untuk variabel efektivitas program diklat (Z) sebesar 0,120; artinya jika pelatihan mengalami kenaikan sebesar 1 satuan, kinerja ASN (Y) akan naik sebesar 0,120. Koefisien bernilai positif antara efektivitas program diklat dan kinerja ASN. Hal ini menunjukan bahwa variable efektivitas diklat memiliki hubungan searah dengan variable kinerja ASN. Hasil ini diperoleh dari alat ukur yang digunakan yaitu indicator yang disajikan dalam bentuk pertanyaan dengan jawaban responden terukur. Pada pertanyaan pertama program Diklat yang dilaksanakan sudah sesuai dengan kebutuhan peserta dan tujuan program Diklat tersaebut. Kebanyakan responden menjawab setuju dengan persentase $47,75 \%$. Selanjutnya pertanyaan pencapaian tujuan program Diklat, harus tergambarkan oleh evaluasi yang dilakukan. Kebanyakan responden menjawab setuju dengan persentase $35,14 \%$. Pertanyaan selanjutnya Diklat yang dilaksanakan hendaknya dapat mengubah psikologi sosial peserta. Kebanyakan responden menjawab setuju dengan persentase $38,74 \%$. Selanjutnya pertanyaan orang yang telah ikut dalam pelaksanaan Diklat, cenderung lebih mudah bersosialisasi dengan rekan kerja dan masyarakat. Kebanyakan responden menjawab setuju dengan persentase 42,34\%. Pada indicator selanjutnya dengan pertanyaan peserta mampu dengan cepat menyesuaikan diri dengan program Diklat yang di ikuti. Kebanyakan responden menjawab setuju dengan persentase $39,64 \%$. Pertanyaan selanjutnya kegiatan Diklat yang dilaksanakan sesuia dengan kultur calon peserta. Kebanyakan responden menjawab setuju dengan persentase 40,99\%.

Pembuktian hipotesis yang di sajikan dalam penelitian ini dilakukan dengan melakukan pengujian terhadap hipotesis. Pengujian hipotesis melihat hubungan langsung maupun tidak langsung yang diuraikan sebagai berikut:

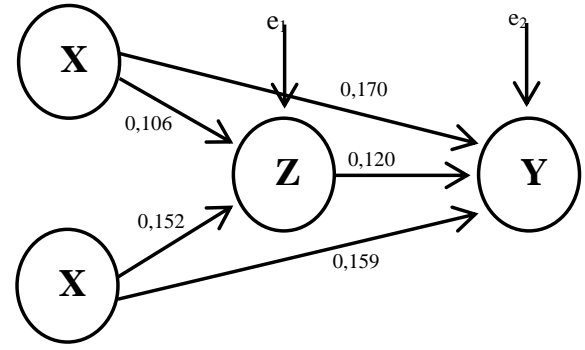

Gambar 2. Distribusi nilai koefisien variabel 
Dari gambar tersebut mengenai dsitribusi niliai koefisien dari 2 persamaan regresi linear berganda dalam penelitian makan dapat dilihat hubungan langsung dan hubungan tidak langsung sebagai berikut:

1) Hubungan langsung antara variabel pendidikan (X1) terhadap efektivitas program diklat (Z) sebesar 0,106 dengan derajat signifikan 0,039 lebih kecil dari 0,05. Sehingga di asumsikan hipotesis pertama diterima. Indicator yang paling besar pengaruhnya adalah metode pada pertanyaan ke tiga dank e empat. Dengan demikian dapat dikatakan bahwa keberhasilan dalam pendidikan untuk membentuk karakter serta mudahnya diserap materi pendidikan oleh peserta dalam diklat dipengaruhi metode yang digunakan.

2) Hubungan langsung antara variabel pelatihan (X2) terhadap efektivitas program diklat (Z) sebesar 0,152 dengan derajat signifikan sebesar 0,047 lebih kecil dari 0,05 . Sehingga di asumsikan hipotesis kedua diterima. Indicator yang paling besar pengaruhnya tertuang dalam pertanyaan dengan tanggapan responden berdasarkan jawaban yang diberikan pada pertanyaan ke Sembilan dan kesepuluh yaitu klasifikasi pelatih. Dengan demikian dapat diasumsikan bahwa klasifikasi pelatih dalam pelatihan hendaknya terukur dengan standarisasi yang dibuat sesuai dengan kebutuhan serta orientasi pelatihan yang akan dilaksanakan sehingga dapat meningkatkan efektivitas program diklat yang dilaksanakan.

3) Hubungan langsung antara variabel pendidikan (X1) terhadap kinerja ASN (Y) sebesar 0,170 dengan derajat signifikan sebesar 0,024 lebih kecil dari 0,05. Sehingga di asumsikan hipotesis ketiga diterima. Indikator yang yang digunakan yaitu kurikulum, metode, dan evaluasi dapat meningkatkan kinerja ASN. Hal ini terlihat dari jawaban responden terhadap pertanyaan yang diberikan terkait dengan pendidikan dan kinerja ASN, yang rata-rata jawaban setuju.

4) Hubungan langsung antara variabel pelatihan (X2) terhadap kinerja ASN (Y) sebesar 0,159 dengan derajat signifikan sebesar 0,012 lebih kecil dari 0,05. Sehingga di asumsikan hipotesis ke empat diterima. Indicator klasifikasi peserta, klasifikasi pelatih, dan waktu yang digunakan yang disajikan dalam bentuk pertanyaan, mejadi dasar asumsi ukuran yang digunakan. Rata-rata responden menjawab setuju.

5) Hubungan langsung antara variabel efektivitas program diklat (Z) terhadap kinerja ASN (Y) sebesar 0,120 dengan derajat signifikan sebesar 0,040 lebih kecil dari 0,05. Sehingga di asumsikan hipotesis kelima diterima. Hubungan efektivitas prigram diklat dan kinerja ASN diukur dengan indicator yang disajikan dalam pertanyaan. Indicator yang lebih besar pengaruhnya adalah pencapaian tujuan pada pertanyaan ke tiga belas dan ke empat belas. Hal ini berarti bahwa untuk meningkatkan kinerja ASN dalam tujuan diklat harus tergambarkan sehingga calon peserta dapat mengetahui serta menyesuaikan dengan kebutuhan dalam peningkatan kinerjanya.

6) Hubungan tidak langsung antara variabel pendidikan (X1) terhadap kinerja ASN (Y) melalui variabel efektivitas program diklat $(Z)$ dengan menggunakan fotmulasi $\mathrm{Y}=\mathrm{X} 1 \mathrm{Z} \times \mathrm{ZY}=0,106 \times 0,120=0,01272$ $(0,013)$. Diketahi hubungan total yang terjadi antara variabel pendidikan (X1) terhadap variabel kinerja ASN (Y) melalui variabel efektivitas program diklat (Y) sebesar X1Z x ZY + X1Y $=(0,106 \times 0,120)+$ $0,170=0,18272(0,183)$. Dapat di asumsikan bahwa hipotesis ke enam diterima.

7) Hubungan tidak langsung antara variabel pelatihan (X2) terhadap kinerja ASN (Y) melalui variabel efektivitas program diklat $(Z)$ dengan menggunakan formulasi $\mathrm{Y}=\mathrm{X} 2 \mathrm{Z} \times \mathrm{ZY}=0.152 \times 0,120=0,01824$ $(0,018)$. Diketahi hubungan total yang terjadi antara variabel platihan (X1) terhadap variabel kinerja ASN (Y) melalui variabel efektivitas program diklat (Y) sebesar X2Z x ZY + X2Y $=(0,152 \times 0,120)+$ $0,159=0,17724(0,177)$. Dapat di asumsikan bahwa hipotesis ketujuh diterima diterima.

Dalam penelitian analisis efektivitas program penyelenggaraan diklat kantor PPSDM Kemendagri Regional Makassar terhadap kinerja ASN ini membahas tentang sejauh mana pengaruh pendidikan dan pelatihan terhadap efektivitas program diklat serta kinerja ASN. Tujuan penelitian untuk melihat dan menganalisa sejauh mana pengaruh variable pendidikan dan penelitian terhadap kinerja ASN, baik secara langsung maupun melalui mediasi variable efektivitas program diklat sebagai intervening. Variabel yang digunakan dalam penelitian ini adalah pendidikan dan pelatihan sebagai variabel independen, kinerja ASN sebagai variabel dependen, serta efektivitas program diklat sebagai variabel intervening. Jenis penelitian ini adalah asosiatif dengan menggunakan regresi linear berganda metode jalur atau path.

Berikut akan di uraikan hubungan antara variabel dalam penelitian ini, baik secara langsung maupun secara tidak langsung.

1) Pengaruh Pendidikan terhadap Efektivitas Program Diklat

Dari hasil pengujian regresi yang dilakukan dalam penelitian ini diketahui bahwa variabel pendidikan memiliki nilai positif terhadap variabel efektivitas program diklat pada PPSDM Kemendagri Regional Makassar. Dapat disimpulkan bahwa pendidikan memiliki pengaruh yang searah terhadap efektivitas program diklat. Makin besar variabel pendidikan maka semakin besar juga kenaikan variabel efektivitas program diklat. Nilai derajat signifikan yang dihasilkan lebih kecil dari standar signifikan yang ditentukan. Indikator-indikator yang digunakan sebagai ukuran variabel pendidikan reability dan valid. Hubungan ini merupaan hubungan langsung.

Asumsi ini tidak sejalan dengan hasil penelitian yang dilakukan oleh Mawar Muchtar (2012) yang berjudul "Efektivitas Pelaksanaan Diklat Prajabatan Pada Badan Kepegawaian, Pendidikan dan Pelatihan Daerah 
Kabupaten Tana Toraja", yang menjelaskan hasil dari penelitiannya yaitu pelaksanaan diklat prajabatan pada Badan Kepegawaian, Pendidikan dan Pelatihan Daerah Kabupaten Tana Toraja belum efektif karena adanya faktor Widyaswara dan sarana dan prasarana yang krang menunjang terselenggaranya diklat tersebut.

2) Pengaruh Pelatihan terhadap Efektivitas Program

Diklat

Varibael pelatihan memiliki pengaruh yang positif terhadap efektivitas program diklat pada PPSDM Kemendagri Regional Makassar. Hal ini ditunjukan oleh hasil regresi yang menunjukan nilai positif dengan derajat signifikan yang lebih kecil dari standar signifikan yang telah ditentukan dalam penelitian ini. Hasil pengujian reabilitasi dan validasi juga menunjukan nilai yang positif. Hal ini membuktikan bahwa indikator-indikator yang yang digunakan dalam menilai variabel peatihan kredibel.

Hasil penelitian ini sejalan dengan penelitian yang dilakukan oleh Grace Yuris Pariambo (2012) dengan judul "Efektivitas Penyelenggaraan Diklat Sistem Pengendalian Intern Pemerintah (Spip) Pada Kantor Badan Pengawasan Keuangan Dan Pembangunan (Bpkp) Perwakilan Propinsi Sulawesi Selatan". Hasil penelitian ini menunjukan efektivitas proses penyelenggaraan diklat SPIP di Kantor BPKP Perwakilan Propinsi Sulawesi Selatan telah berjalan dengan cukup baik sesuai dengan indikator pengukuran efektivitas, walaupun dalam beberapa sisi masih terdapat kelemahan yang perlu dibenahi khususnya pengembangan tenaga pengajar kelengkapan sarana dan prasarana dan peningkatan jumlah anggaran diklat untuk mencapai penyelenggaraan diklat SPIP yang lebih baik. Hubungan pelatihan terhadap efektivitas program diklat pada PPSDM Kemendagri Regional Makassar merupakan hubungan langsung dalam penelitian ini.

3) Pengaruh Pendidikan terhadap Kinerja ASN

Variabel pendidikan terhadap kinerja ASN memiliki pengaruh yang psitif. Hal ini ssuai dengan hasil regresi yang ditujunkan bernilai positif dimana derajad signifikan lebih kecil dari nilai signifikan yang telah ditentukan. Indikator-indikator yang digunakan untuk mengukur variabel pendidikan terhadap kinerja kredibel, yang menunjukan nilai lebih besar dari nilai standar yang ditentukan untuk mengukur kekuatan validasi dan reabilitasinya. Hasil penelitian ini sejalan atau memperkuat.

4) Pengaruh Pelatihan terhadap Kinerja ASN

Varibael pelatihan memiliki pengaruh yang positif terhadap kinerja ASN pada PPSDM Kemendagri Regional Makassar. Hal ini ditunjukan oleh hasil regresi yang menunjukan nilai positif dengan derajat signifikan yang lebih kecil dari standar signifikan yang telah ditentukan dalam penelitian ini. Hasil pengujian reabilitasi dan validasi juga menunjukan nilai yang positif. Hal ini membuktikan bahwa indikator-indikator yang yang digunakan dalam menilai variabel peatihan kredibel.
Hasil penelitian ini sejalan dengan penelitian yang dilakukan oleh Denni Triasmoko (2014) dengan judul "Pengaruh Pelatihan Kerja Terhadap Kinerja Karyawan (Penelitian Pada Karyawan PT Pos Indonesia (Persero) Cabang Kota Kediri)". Hasil pengujian secara parsial variabel metode pelatihan berpengaruh signifikan terhadap variabel kinerja karyawan. Hubungan pelatihan terhadap kinerja ASN pada PPSDM Kemendagri Regional Makassar merupakan hubungan langsung dalam penelitian ini.

5) Pengaruh Efektivitas Program Diklat terhadap Kinerja ASN

Varibael efektivitas program diklat memiliki pengaruh yang positif terhadap kinerja ASN pada PPSDM Kemendagri Regional Makassar. Hal ini ditunjukan oleh hasil regresi yang menunjukan nilai positif dengan derajat signifikan yang lebih kecil dari standar signifikan yang telah ditentukan dalam penelitian ini. Hasil pengujian reabilitasi dan validasi juga menunjukan nilai yang positif. Hal ini membuktikan bahwa indikator-indikator yang yang digunakan dalam menilai variabel efektifitas program diklat kredibel.

Hasil penelitian ini sejalan dengan penelitian yang dilakukan oleh Andi Passamula (2017) dengan judul "Analisis Pengaruh Diklat Dan Lingkungan Kerja Terhadap Kinerja Pegawai Di Badan Lingkungan Hidup Daerah Kabupaten Wajo". Hasil pengujian pengukuran menunjukkan bahwa variabel yang paling domiman memengaruhi kinerja adalah pendidikan \& pelatihan (Diklat), hal ini dikarenakan untuk variabel tersebut mempunyai nilai koefisien regresi terbesar serta memiliki nilai signifikan yang terkecil dari variabel yang lain. Hubungan pelatihan terhadap kinerja ASN pada PPSDM Kemendagri Regional Makassar merupakan hubungan langsung dalam penelitian ini.

6) Pengaruh Pendidikan terhadap Kinerja ASN melalui Efektivitas Program Diklat

Variabel pendidikan melalalui efektivitas program diklat memiliki pengaruh yang positif terhadap kinerja ASN pada PPSDM Kemendagri Regional Makassar. Hal ini ditunjukan oleh hasil regresi yang menunjukan nilai positif dengan derajat signifikan yang lebih kecil dari standar signifikan yang telah ditentukan dalam penelitian ini. Disimpulkan bahwa jika pendidikan dihubungkan ke variabel kinerja melalui variabel efektivitas progam diklat, maka akan mempengaruhi secara positif. Hubungan ini dikatakan hubungan tidak langsung antara variabel pendidikan terhadap variabel kinerja ASN.

Nilai total yang ditunjukan hubungan tidak langsung ini lebih besar terhadap hubungan langsung. Sehingga di asumsikan bahwa untuk meningkatkan kinerja ASN maka lebih baik menghubungkan pendidikan melalui efektivitas diklat terhadap kinerja ASN pada PPSDM Kemendagri Regional Makassar.

7) Pengaruh Pelatihan terhadap Kinerja ASN melalui Efektivitas Program Diklat

Variabel pelatihan melalalui efektivitas program diklat memiliki pengaruh yang positif terhadap kinerja 
ASN pada PPSDM Kemendagri Regional Makassar. Hal ini ditunjukan oleh hasil regresi yang menunjukan nilai positif dengan derajat signifikan yang lebih kecil dari standar signifikan yang telah ditentukan dalam penelitian ini. Disimpulkan bahwa jika pelatihan dihubungkan ke variabel kinerja melalui variabel efektivitas progam diklat, maka akan mempengaruhi secara positif. Hubungan ini dikatakan hubungan tidak langsung antara variabel pendidikan terhadap variabel kinerja ASN.

Nilai total yang ditunjukan hubungan tidak langsung ini lebih besar terhadap hubungan langsung. Sehingga di asumsikan bahwa untuk meningkatkan kinerja ASN maka lebih baik menghubungkan pelatihan melalui efektivitas diklat terhadap kinerja ASN pada PPSDM Kemendagri Regional Makassar.

\section{KESIMPULAN DAN SARAN}

Hasil penelitian menyimpulkan bahwa pendidikan melalalui efektivitas program diklat memiliki pengaruh yang positif terhadap kinerja ASN pada PPSDM Kemendagri Regional Makassar. Hal ini ditunjukan oleh hasil regresi yang menunjukan nilai positif dengan derajat signifikan yang lebih kecil dari standar signifikan yang telah ditentukan dalam penelitian ini. Disimpulkan bahwa jika pendidikan dihubungkan ke variabel kinerja melalui variabel efektivitas progam diklat, maka akan mempengaruhi secara positif. Hubungan ini dikatakan hubungan tidak langsung antara variabel pendidikan terhadap variabel kinerja ASN. Pelatihan melalalui efektivitas program diklat memiliki pengaruh yang positif terhadap kinerja ASN pada PPSDM Kemendagri Regional Makassar. Hal ini ditunjukan oleh hasil regresi yang menunjukan nilai positif dengan derajat signifikan yang lebih kecil dari standar signifikan yang telah ditentukan dalam penelitian ini. Disimpulkan bahwa jika pelatihan dihubungkan ke variabel kinerja melalui variabel efektivitas progam diklat, maka akan mempengaruhi secara positif. Hubungan ini dikatakan hubungan tidak langsung antara variabel pendidikan terhadap variabel kinerja ASN.

\section{DAFTAR PUSTAKA}

Barbazette (2013) Analisis Faktor-faktor yang mempengaruhi efektivitas pelatihan penjualan dan kompetensi relasional untuk meningkatkan kinerja tenaga penjualan. Tesis. Universitas Diponegoro.

Basri, Ahmad, (2017). Pemahaman Praktis Manajemen Sumber Daya Manusia, Universitas Tanjung Pura, Mandar Maju, Bandung

Biech, Elaine, (2014). Training For Dummies by Elain Biech. New York: Mc. Edisi Terjemahan, Jakarta: Erlangga.

Bungkaes (2013) Departemen Pendidikan Nasional, Kamus Besar Bahasa Indonesia Edisi Ketiga, Balai Pustaka, Jakarta
Chan, Janis Fisher. (2015). Training Fundamentals: Pfeiffer Essential Guides To Training Basics, terjemahan , Jakarta: Erlangga.

Desser, Gary, (2014). Human Resource Management. New Jersey: Prentice Hall, Edisi Terjemahan, Jakarta: Erlangga.

Gomes, R. (2013). Competency Management. Jakarta: Penerbit PPM

Hadari Nawawi. (2013). Manajemen Sumber Daya Manusia Untuk Bisnis Yang Komptitif gadjah Mada University Press, Yogyakarta

Handoko, Hani, (2014), Manajemen, Edisi Revisi, BPFE, Yogyakarta.

Harsono MS, (2014). Perencanaan dan Pengembangan SDM. Bandung: Alfabeta.

Jaspin, S. W., Ruslan, M., \& Sapiri, M. (2020). Pengaruh Gaya Kepemimpinan Transformasional, Budaya Kerja Dan Komitmen Terhadap Kepuasan Kerja Anggota Polri Bidpropam Polda Sulawesi Selatan. Indonesian Journal of Business and Management, 3(1), 58-65.

Lijan Poltak Sinambela, (2015). Manajemen Sumber Daya Manusia : Membangun Tim Kerja yang Solid untuk Meningkatkan Kinerja. Jakarta: Bumi Aksara.

M.A. Rahman, (2014). Manajemen Sumber Daya Manusia, Teori dan Aplikasi, Bandung: Alfabeta

Malayu S. P. Hasbuan, (2014). Manajemen Sumber Daya Manusia. Edisi Revisi, Jakarta: PT. Bumi Aksara.

Marimba, Ahmad D. (2012). Filsafat Pendidikan Dasar, Jakarta: Erlangga

Martani S, AM. Lubis, (2014). Perencanaan dan Pengembangan SDM, Bandung : Alfabeta

Mas'ud, Fuad. (2016). Survai Diagnosis Organisasional: Konsep dan Aplikasi. Semarang: Badan Penerbit Universitas Diponegoro.

Mathis Robert L. Dan Jackson John H. (2015), Human Resource Management, Ahlih Bahasa. Salemba Empat. Jakarta.Mangkunegara

MPRS No. 2 Tahun 1960 Pancasila Sebagia Sumber Dari Tertib atau Tata Hukum RI

Muhammad Anwar, (2015). Filsafat Pendidikan, Jakarta: Rajawalai PersZais

Nitisemito (2013). Evaluasi Pelatihan Dalam Rangka Meningkatkan Produktivitas Perusahaan. Bandung: Mandar Maju.

Noe, Raymond A., (2015). Human Resource Management, Gaining Competitive Advantage $3^{\text {rd }}$ Editions. Edisi Terjemahan, Bandung: Polban.

Nurhayati (2015). Pelatihan dan pengembangan untuk meningkatkan kinerja SDM . Jakarta: CV Alfabeta.

Pasolong, Harbani. (2015). Teori Administrasi Publik. Bandung: Alfabeta.

PP Nomor 101 Tahun 2000 tentang Pendidikann dan Pelatihan Jabatan Pegawai Negeri Sipil

PP Nomor 11 Tahun 2017 Tentang Manajemen Pegawai Negeri Sipil

Ravianto (2014). Manajemen Sumber Daya Manusia. Erlangga, Jakarta. 
Richard M. Steers (2014). Manajemen Sumber Daya Manusia. Jakarta: Erlangga.

Rivai, Basr. (2015). Manajemen Sumber Daya Manusia Untuk Perusahaan Dari Teori ke Praktik. Jakarta: Raja Grafindo Persada.

Ruky A. (2016). Sistem Manajemen Kinerja. Jakarta: Gramedia.

Sadili Samsuddin, (2015) Manajemen Personalia dan Sumber Daya Manusia. Yogyakarta: BPFE

Schemerhon John R. Jr, (2014). Human Resource Management for Public and Nonprofit Organizations. San Fransisco: Jossey Bass. Edisi Terjemahan, Jakarta: PT. Prehaltindo.

Shein Caple N, (2016). Organitation Dynamic, The Founder in Creating Organizational Cultute. Edisi Terjemahan, Jakarta: Indeks.

Sikula, Andrew F. (2014). Sistem Manajemen Kinerja. Edisi Terjemahan. Jakarta: Gramedia Pustaka Utama.

Simamora (2016) Pelatihan dan Pengembangan SDM, Bandung: Fakultas Psikology UNPAD

Siswanto, Bambang. (2013). Manajemen Pemerintahan Dalam Perspektif Pelayanan Publik. Jakarta: Mitra Wacana Media

Sondang P. S. (2014). Manajemen Sumber Daya Manusia: Dasar dan Kunci Keberhasilan. Jakarta: Haji Masagung.

Sugiyono. (2016). Statistika Untuk Penelitian. Bandung: Alfabeta.

Sumarsono, (2017). Manajemen Sumber Daya Manusia, Perencanaan dan Pengembangan. Bandung: Pustaka Setia.

Sunyoto, Danang. (2014). Teori, Kuesioner, Dan Analisis Data Sumber Daya Manusia. Center For Academic Publishing Service: Yogyakarta.

Tyson, Shaun. (2014). Essentials Of Human Resource Management. United Kingdom: Elsever Ltd. Edisi Terjemahan, Jakarta: Erlangga.

UU No. 2 Tahun 1985 Tentang Pendidikan Nasional

UU Nomor 5 Tahun 2014 Tentang Aparatur Sipil Negara

UU. No.20 Tahun 2003 pasal 3 Tentang Tujuan Pendidikan Nasional

Werther Jr, dan Keith Davis, (2017). Human Resource and Personnel Management. Singapore: Mc Graw Hill. Edisi Terjemahan, Jakarta: PT. Indeks.

Yuniarsih dan Suwatno. (2015). Pengaruh Pelatihan Dan Motivasi Terhadap Prestasi Kerja Karyawan Studi Kasus Di Auto 2000 Indramayu. 